\title{
Function and localization of oxytocin receptors in the reproductive tissue of rams
}

\author{
K. Whittington ${ }^{1}$, S. J. Assinder ${ }^{1}$, T. Parkinson ${ }^{2}$, \\ K. R. Lapwood ${ }^{2}$ and H. D. Nicholson ${ }^{1}$ \\ ${ }^{1}$ University of Bristol, Department of Anatomy, School of Veterinary Science, Southwell \\ Street, Bristol BS2 8EJ, UK; and 2 Institute of Veterinary, Animal and Biomedical Sciences, \\ Massey University, Private Bag 11-222, Palmerston North, New Zealand
}

\begin{abstract}
Oxytocin is present in the male reproductive tract and has been shown to increase contractility in the epididymis and to modulate steroidogenesis. This study investigated the effects of oxytocin in the testis in vivo, and the presence and cellular localization of oxytocin receptors in the reproductive tract of rams. During the breeding season, mature rams underwent efferent duct ligation before injection of either oxytocin $(20 \mu \mathrm{g})$ or oxytocin plus an oxytocin antagonist $(20 \mu \mathrm{g})$ into the testicular artery; the contralateral testicular artery received saline. Injection of oxytocin caused a significant increase $(P<0.05)$ in the concentration of spermatozoa collected from the rete testis. This effect was not observed after treatment with the oxytocin antagonist plus oxytocin. Western blot analysis performed using a specific oxytocin receptor antibody
\end{abstract}

(020) identified a single immunoreactive band of $66 \mathrm{kDa}$ in testicular and epididymal tissue. This band was present in uterine tissue but not in liver or muscle. Immunocytochemistry identified oxytocin receptors on Leydig and Sertoli cells of the testis, on epithelial cells throughout the epididymis, on peritubular smooth muscle cells in the cauda epididymidis, and on the epithelial cells and circular smooth muscle layer of the ductus deferens. These findings indicate that oxytocin can modulate sperm transport in the ram testis. A role for oxytocin in promoting sperm transit is supported by the localization of oxytocin receptors in the cauda epididymis and ductus deferens, and the presence of receptors on Leydig, Sertoli and epididymal epithelial cells provides further evidence that oxytocin may be involved in the local regulation of steroidogenesis.

\section{Introduction}

Local production of oxytocin in the male reproductive tract is an established event that is linked to two major physiological functions, namely tract contractility and steroidogenesis. In rats, oxytocin increases the contractility of the seminiferous tubules in a manner that is dependent on both dose (Worley et al., 1988) and the stage of the spermatogenic cycle (Harris and Nicholson, 1998). Modulation of such contractile activity in rats is thought to promote sperm transfer into the epididymis and may also affect spermiation (Frayne et al., 1996). Contractility of the epididymis, both in vitro (Hib, 1974) and in vivo (Knight, 1974), is increased by oxytocin, resulting in a specific increase in sperm transport through the epididymis (Nicholson et al., 1999). Contractile activity of both the ductus deferens (Knight, 1974) and the prostate gland (Bodanszky et al., 1992) is also stimulated by oxytocin.

Oxytocin is also implicated in steroidogenesis: it is known to stimulate testosterone secretion by Leydig cells in vitro (Frayne and Nicholson, 1995) and also increases the activity of $5 \alpha$-reductase throughout the male reproductive

Email: K.Whittington@bris.ac.uk tract (Nicholson and Jenkin, 1994), thereby increasing the local concentration of the biologically active androgen dihydrotestosterone (Nicholson et al., 1991).

For oxytocin to exert these actions in the male reproductive tract, functional receptors must be present. Oxytocin receptors are present on Leydig cells in human, macaque (Frayne and Nicholson, 1998), marmoset (Einspanier and Ivell, 1997) and rat (Bathgate and Sernia, 1994) testes. In humans and macaques, immunoreactive staining for these receptors is also present on Sertoli cells (Frayne and Nicholson, 1998). To date, the presence of oxytocin receptors has not been demonstrated on testicular myoid cells (the cells responsible for seminiferous tubule contractility), although, at least in rats, vasopressin receptors have been demonstrated in these cells (Howl et al., 1995). Evidence of oxytocin binding sites in the epididymis was first provided by Maggi et al. (1987). Subsequently, these receptors have been localized to the peritubular smooth muscle layer of the epididymides of both macaques (Frayne and Nicholson, 1998) and marmosets (Einspanier and Ivell, 1997).

Local expression of oxytocin in the testis and epididymis increases during puberty (Assinder et al., 2000) and oxytocin specifically increases sperm transport from the epididymis (Nicholson et al., 1999), indicating the presence 
of, and a role for, oxytocinergic systems in the reproductive tract of male sheep. However, to date, neither a physiological role for oxytocin in the ram testis, nor the presence of specific oxytocin receptors in the reproductive tract of rams has been described. Both of these factors are prerequisites for the confirmation of physiologically significant oxytocinergic systems within the male reproductive tract. The present study aimed to: (i) investigate whether oxytocin increases sperm movement within ram testes; and (ii) identify and demonstrate the cellular localization of oxytocin receptors during sexual maturation.

\section{Materials and Methods}

\section{Effects of oxytocin and oxytocin antagonist on sperm transport in the ram testis}

Fifteen Oxford Down crossbred adult rams were used to investigate the effects of oxytocin and a specific oxytocin antagonist (desGly- $\mathrm{NH}_{2}, \mathrm{~d}\left(\mathrm{CH}_{2}\right)_{5}-\left[\mathrm{d}-\mathrm{Tyr}^{2}, \mathrm{Thr}^{4}\right]$-ornithine vasotocin) (Manning et al., 1995) on the concentration of spermatozoa in rete testis fluid. Rams were used during the breeding season (June) and were kept under the ambient photoperiods prevalent in the Manawatu district of New Zealand (latitude $40^{\circ}$ South). The rams were penned individually throughout the experiments, in sight and sound of other sheep, and were provided with forage (dried grass pellets) and water ad libitum.

Anaesthesia was induced with i.v. injection of Saffan (3 $\mathrm{mg} \mathrm{kg}^{-1}$ ) (Pitman-Moore, Upper Hutt) and was maintained with halothane $(2-3 \%)$ in oxygen. Efferent duct ligation was performed as described by Setchell (1970). Briefly, the caput epididymidis was exposed through a scrotal incision and carefully dissected free from the testis until the efferent duct was visualized. The duct was ligated using a double silk tie. The epididymis and testis were then replaced in the scrotum, the wound sutured and the animal allowed to recover from the anaesthesia. At the time of surgery, each animal was administered $100 \mu \mathrm{l}$ saline into one testis, and either $100 \mu \mathrm{l}$ saline $(n=5), 20 \mu \mathrm{g}$ oxytocin in $100 \mu \mathrm{l}$ saline $(n=5)$ or $20 \mu \mathrm{g}$ oxytocin plus $20 \mu \mathrm{g}$ oxytocin antagonist in $100 \mu \mathrm{l}$ saline $(n=5)$ was administered into the contralateral testis. All injections were administered into a major testicular artery running along the epididymal margin of the testis. Treatment was allocated randomly so that neither the right nor the left testis was favoured consistently in administration of treatment or control injections.

Twenty-four hours after efferent duct ligation, each animal was castrated under general anaesthesia. Each testis was dissected free and weighed. A fine needle was passed into the rete testis and the accumulated rete testis fluid was aspirated. The concentration of spermatozoa in the rete testis fluid was measured using a haemocytometer. Each sample was measured in at least two dilutions. Three separate aliquots were assessed for each sample and ten $0.1 \mu \mathrm{m}$ squares were counted for each aliquot. Mean sperm counts for each treatment were compared with those of the control contralateral testis treated with saline, by Student's $t$ tests.

\section{Localization of oxytocin receptors in the reproductive tract of rams}

Production of a polyclonal antiserum to the oxytocin receptor and confirmation of its specificity. A polyclonal antibody was raised in New Zealand white rabbits against a synthetic peptide, WQNLRLKTAAAA, from the predicted amino acid sequence of the third intracellular loop of the sheep oxytocin receptor (Adan et al., 1995). The peptide was conjugated to keyhole limpet haemocyanin and BSA using a carbodiimide reaction. A rabbit (020) was first immunized with a 1:1 mixture of the keyhole limpet haemocyanin coupled peptide in complete Freund's adjuvant (1 mg in $1 \mathrm{ml}$ ). A booster was administered 5 weeks after the initial immunization and subsequently at 3 week intervals using the BSA-conjugated peptide. Blood samples were obtained from the ear vein at 8 and 12 weeks after the initial immunization and the sera were assessed for immunoreactivity by Western blot analysis using tissue known to be positive for the oxytocin receptor. A final collection of blood was made 15 weeks after the initial immunization, and sera were evaluated, as before, to determine specificity and optimal working dilutions.

Crude tissue extracts of sheep uterus, skeletal muscle, testis and epididymis (from a mature ram) were prepared by homogenizing $0.5 \mathrm{~g}$ tissue in $2 \mathrm{ml}$ PBS $(154 \mathrm{mmol} \mathrm{NaCl}$ $\mathrm{I}^{-1}, 1.9 \mathrm{mmol} \mathrm{NaH}_{2} \mathrm{PO}_{4} \mathrm{I}^{-1},\left.8.1 \mathrm{mmol} \mathrm{Na}{ }_{2} \mathrm{HPO}_{4}\right|^{-1}, \mathrm{pH} 7.2$ ) containing 'complete' mini protease inhibitor cocktail tablets (Boehringer Mannheim UK, Lewes) at the concentration recommended by the manufacturer. Protein extracts were mixed with equal volumes of SDS reducing buffer (62.5 mmol Tris $\mathrm{I}^{-1}$, $\mathrm{pH}$ 6.8, 2\% (w/v) SDS, 10\% (v/v) glycerol, $100 \mathrm{mmol}$ dithiothreitol $\mathrm{I}^{-1}, 0.05 \%$ (w/v) bromophenol blue) and incubated in a boiling waterbath for $5 \mathrm{~min}$ before loading. Proteins were separated according to size by discontinuous SDS-PAGE, under reducing conditions on $10 \%$ polyacrylamide gels and electroblotted on to polyvinylidene difluoride (PVDF) (Boehringer Mannheim UK) membranes. Western blots were probed for $1 \mathrm{~h}$ at room temperature with: (i) antiserum 020, diluted 1:4000 in PBS with $0.02 \%(\mathrm{v} / \mathrm{v})$ Tween 20 and $3 \%(\mathrm{w} / \mathrm{v})$ milk protein; (ii) antiserum 020, diluted as above but which had been preincubated with a square of PVDF which had a $5 \%(\mathrm{w} / \mathrm{v})$ solution of the synthetic peptide dot blotted on to it; or (iii) antiserum OTrec, which was raised to a different nonoverlapping region of the third intracellular loop of the oxytocin receptor peptide sequence GRAALARV (Adan et al., 1995). Antiserum OTrec (a kind gift from F. van Leeuwen, Netherlands Brain Institute, Amsterdam) was used at a dilution of 1:4000 in PBS with $0.02 \%(\mathrm{v} / \mathrm{v})$ Tween20 and $3 \%(\mathrm{w} / \mathrm{v})$ milk protein. Membranes were washed and incubated with horseradish peroxidase-conjugated swine anti-rabbit immunoglobulins (diluted 1:2000 in PBS with $0.02 \%(\mathrm{v} / \mathrm{v})$ Tween-20 and 3\% (w/v) milk protein) for 
$1 \mathrm{~h}$ at room temperature. Membranes were washed in PBS before detection of bound antibody by chemiluminescence (BM chemiluminescence (POD); Boehringer Mannheim UK) and exposure of membranes to Hyperfilm (Amersham International, Amersham).

Determination of the presence and localization of the oxytocin receptor during puberty. Poll-Dorset crossbred rams $(n=30)$ aged between 2 and 7 months were used in the experiments. Individuals were removed from the flock from May to October. The flock was grazing in pasture in the Bristol area, UK. Rams were housed under photoneutral conditions (12 h light:12 h dark) for a maximum of $24 \mathrm{~h}$, and had free access to hay and water. Animals were killed by an injection of $150 \mathrm{mg}$ sodium pentobarbitol $\mathrm{kg}^{-1}$ (Euthatol; Rhone Merieux, Harlow), and testes and epididymides were removed. Samples of testis and epididymis from all animals were either stored at $-20^{\circ} \mathrm{C}$ until required, or were fixed ( $24 \mathrm{~h}$ ) in modified Bouin's solution, then dehydrated and embedded in paraffin wax.

Sections $(5 \mu \mathrm{m})$ of fixed testis tissue from all animals were stained with haematoxylin and eosin. The stage of the first spermatogenic wave in each ram was assessed according to the appearance of predetermined landmarks in the seminiferous tubules. Prepubertal stages were determined as those with only type A spermatogonia $(n=2)$. The appearance of pachytene spermatocytes was used to define the early pubertal stage $(n=7)$, followed by the presence of early spermatids $(n=6)$ and subsequently late spermatids $(n=7)$ as the cytoplasm remodelled and moved away from the flagellum during spermatid elongation. Full spermatogenesis was assigned to those samples that had residual bodies present, indicating that spermiation had occurred $(n=8)$. Determination of the stage of the spermatogenic wave was confirmed by testis mass and sperm counts (Assinder et al., 2000).

Western blot analysis for the presence of oxytocin receptor. Crude tissue extracts from rams at various stages of sexual maturity were prepared as described above. Equal concentrations $(200 \mu \mathrm{g})$ of total protein were mixed with equivalent volumes of SDS reducing buffer and treated as described above. Proteins were separated according to size by SDS-PAGE under reducing conditions on $10 \%$ polyacrylamide gels and electroblotted onto PVDF. Blots were probed with Antiserum 020, diluted 1:2000 in PBS with $0.02 \%(\mathrm{v} / \mathrm{v})$ Tween-20 and $3.0 \%$ (w/v) milk protein, for $1 \mathrm{~h}$ at room temperature. Membranes were washed and incubated with horseradish peroxidase-conjugated swine anti-rabbit immunoglobulins (1:2000 diluted in PBS with $0.02 \%(\mathrm{v} / \mathrm{v})$ Tween-20 and 3.0\% (w/v) milk protein) for $1 \mathrm{~h}$ at room temperature. Detection of bound antibody was achieved by chemiluminescence (BM chemiluminescence (POD), Boehringer Mannheim UK) and exposure to Hyperfilm (Amersham International).
Immunocytochemical localization of the oxytocin receptor. Samples of testicular, epididymal and ductus deferens tissue were fixed (24 h) in modified Bouin's solution, dehydrated and embedded in paraffin wax. Paraffin wax was removed from the sections (5 $\mu \mathrm{m})$ using xylene before the sections were rehydrated. A high temperature antigen retrieval step was included in the staining protocol, during which sections were completely immersed in preheated EDTA (1 mmol $\mathrm{I}^{-1}, \mathrm{pH}$ 8.0) and heated in a microwave oven for $10 \mathrm{~min}$ (high heat setting). After heating, sections were allowed to cool for $15 \mathrm{~min}$ in the EDTA solution and were washed twice with distilled water. Sections were rinsed in Tris-buffered saline $(25 \mathrm{mmol}$ Tris $\mathrm{I}^{-1}, 0.15 \mathrm{~mol}$ sodium chloride $\mathrm{I}^{-1}, \mathrm{pH} 7.6$ ) for $30 \mathrm{~min}$ followed by two 30 min washes in Tris-buffered saline with $0.5 \%$ (v/v) Triton-X100 and a 30 min wash in Tris-buffered saline with $0.5 \%(\mathrm{v} / \mathrm{v})$ Triton-X100 and $3 \%(\mathrm{w} / \mathrm{v})$ BSA. Endogenous biotin was blocked in all sections by incubation with avidin $\left(1 \mathrm{mg} \mathrm{ml}^{-1}\right)$ for $20 \mathrm{~min}$, followed by incubation with biotin $\left(0.1 \mathrm{mg} \mathrm{ml}^{-1}\right)$ for $20 \mathrm{~min}$. Sections were then rinsed with Tris-buffered saline. Tissue sections were incubated overnight at $4^{\circ} \mathrm{C}$ with antiserum 020 (diluted 1:150 in Tris-buffered saline with 0.5\% (v/v) TritonX100 and 3\% (w/v) BSA). Sections were washed in Trisbuffered saline with $0.5 \%(\mathrm{v} / \mathrm{v})$ Triton-X100 and incubated with a biotin-conjugated goat anti-rabbit immunoglobulin (Sigma Chemical Co., Poole), diluted 1:200 in Tris-buffered saline with $0.5 \%(\mathrm{v} / \mathrm{v})$ Triton-X100 and 3\% (w/v) BSA, for $1 \mathrm{~h}$ at room temperature. Incubation was followed by two 20 min washes in Tris-buffered saline. Sections were incubated with a solution of avidin complexed with biotinylated horseradish peroxidase (ABComplex/HRP; Dako Ltd, High Wycombe) for 30 min. Sections were washed three times in Tris-buffered saline for $20 \mathrm{~min}$ followed by two $15 \mathrm{~min}$ washes in $25 \mathrm{mmol}$ Tris $\mathrm{I}^{-1}$ (pH 7.6). Immunoreactive peptide was visualized using hydrogen peroxidase $\left(2 \mathrm{mg} \mathrm{ml}^{-1}\right)$ and diaminobenzidine $\left(0.7 \mathrm{ng} \mathrm{ml}^{-1}\right)$ in $0.06 \mathrm{mmol}^{\text {Tris- }} \mathrm{HCl} \mathrm{I}^{-1}$ (pH 7.5) (Fast DAB, Sigma Chemical Co.). Sections were counterstained with haematoxylin before dehydration and mounting in DPX medium $(\mathrm{BDH})$. Control sections were incubated with normal rabbit serum in place of primary antiserum to indicate the presence of non-specific immunoreactivity.

\section{Results}

\section{Effects of oxytocin and oxytocin antagonist on sperm transport in rams}

An initial pilot study was performed to validate the technique. In this study, efferent duct ligation was performed on one testis, and on the contralateral side the duct was exposed but not ligated. The study demonstrated that there was an increase in testicular mass after efferent duct ligation (as originally described and validated by Setchell (1970); data not shown).

Treatment with oxytocin or oxytocin plus antagonist had 
(a)

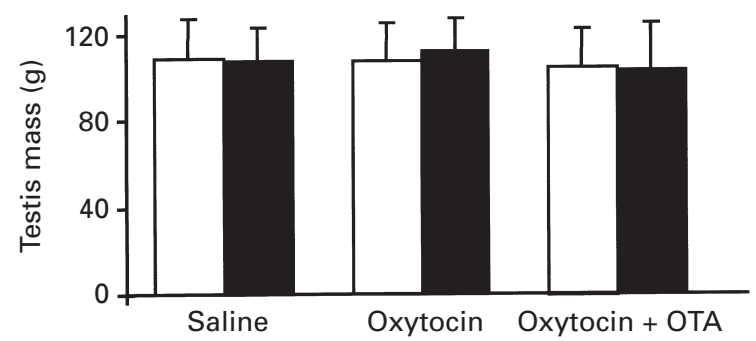

(b)

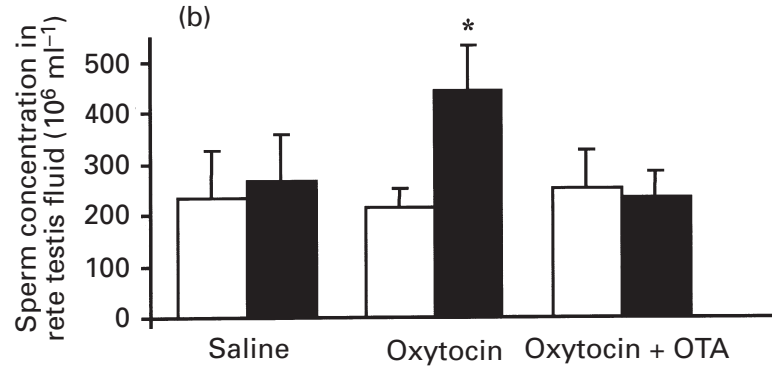

Fig. 1. Effect of oxytocin and oxytocin plus antagonist (OTA) on (a) testicular mass and (b) the concentration of spermatozoa in rete testis fluid in rams. In each ram, one testis received treatment ( $\square$ (saline, oxytocin or OTA; $n=5$ per treatment) and the contralateral testis acted as a control $(\square)$. *Indicates that there is a significant difference between treated and control testes $(P<0.05)$.

no effect on testicular mass compared with the saline-treated testis (Fig. 1a). Administration of oxytocin significantly increased the concentration of spermatozoa in the rete testis fluid compared with the controls $\left(443 \pm 87 \times 10^{6} \mathrm{ml}^{-1}\right.$ compared with $216 \pm 38 \times 10^{6} \mathrm{ml}^{-1}$, respectively; $P<0.05$; Fig. 1b). However, no increase in sperm concentration of the rete testis was observed when the oxytocin antagonist was administered concomitantly with oxytocin (Fig. 1b).

\section{Generation of a polyclonal antibody to the oxytocin receptor}

Western blot analysis using antiserum 020 showed the presence of a single $66 \mathrm{kDa}$ band in both testicular and epididymal tissues of rams. This band was also present in uterine tissues, but was not detected in muscle (Fig. 2, gel A). A band of the same size was present in the same tissues when antiserum OTrec was used to probe the western blot membranes (Fig. 2, gel B). When western blots were carried out using antiserum 020 from which the antibody had been preadsorbed, the single band at $66 \mathrm{kDa}$ was not detected (Fig. 2, gel C). A similar sized band for the oxytocin receptor has been reported in the endometrium and myometrium of pregnant sheep (Xuan et al., 1996).

\section{Western blot analysis for oxytocin receptor}

Western blot analysis using antiserum 020 showed the presence of a $66 \mathrm{kDa}$ protein in testicular (Fig. 3a) and epididymal (Fig. 3b) tissue homogenates. In the testis, the

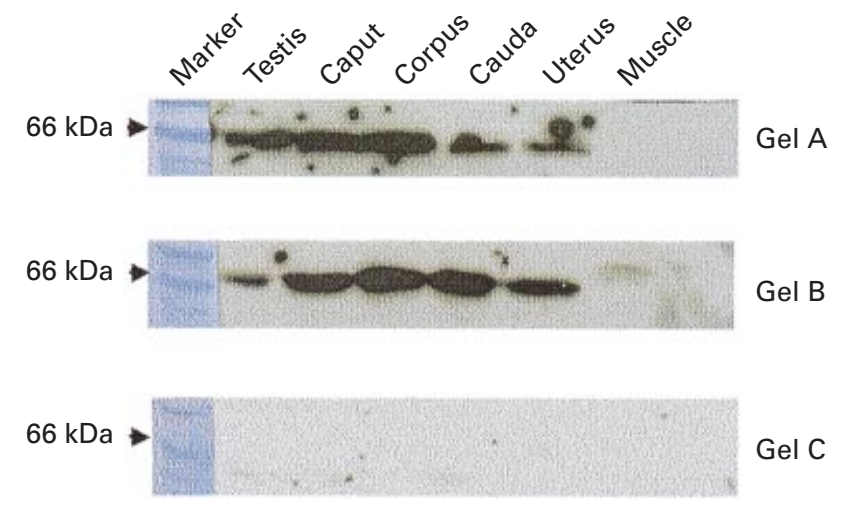

Fig. 2. Western blot analysis of membrane extracts from ram testis, caput epididymis, corpus epididymis and cauda epididymis. Total protein $(200 \mu \mathrm{g})$ was loaded per lane. Uterus and muscle were included as positive and negative controls, respectively. Gels were probed with either 020 antiserum (gel A), OTrec antiserum (gel B) or 020 antiserum preadsorbed with antigen (gel C).

protein was present in all animals and there was no change in the density of bands with the onset of spermatogenesis. Similar findings were observed in the caput and cauda epididymides.

\section{Immunocytochemical localization of oxytocin receptors}

Rat uterine tissue, which was used as a positive control, confirmed the specificity of the primary antibody. Positive immunoreactivity was observed in the glandular tissue of the endometrium and the musculature of the myometrium (Fig. 4F); sections treated with normal rabbit serum showed no such staining (Fig. 4f).

Oxytocin receptors were present on both Leydig and Sertoli cells in sections of testis derived from rams at all stages of development (Fig. 4A-E). The intensity of staining was greater in Sertoli cells than in Leydig cells, and within Sertoli cells immunoreactivity was most marked in the basal region of the seminiferous tubules (that is, below the pachytene spermatocytes; Fig. 4G,H). Immunoreactivity was also noted over the region of the acrosomal vesicle in spermatids that were starting to form an acrosomal hemisphere over their nuclear surface (Fig. 4I). No staining was apparent on the myoid cell layer that surrounded the seminiferous tubules. Although the cellular localization of staining for oxytocin receptors was similar throughout the stages of development, there appeared to be an increase in the intensity of staining as the germinal epithelium progressed beyond the spermatogonia only stage (Fig. 4A-E).

In the epididymis, there were differences in the localization of the receptor between the caput and cauda regions. In both the caput and cauda epididymides, staining for the receptor was present throughout all epithelial cells (Fig. 5A,B). However, in the caput epididymis, no staining was apparent on the peritubular smooth muscle layer (Fig. 
(a)
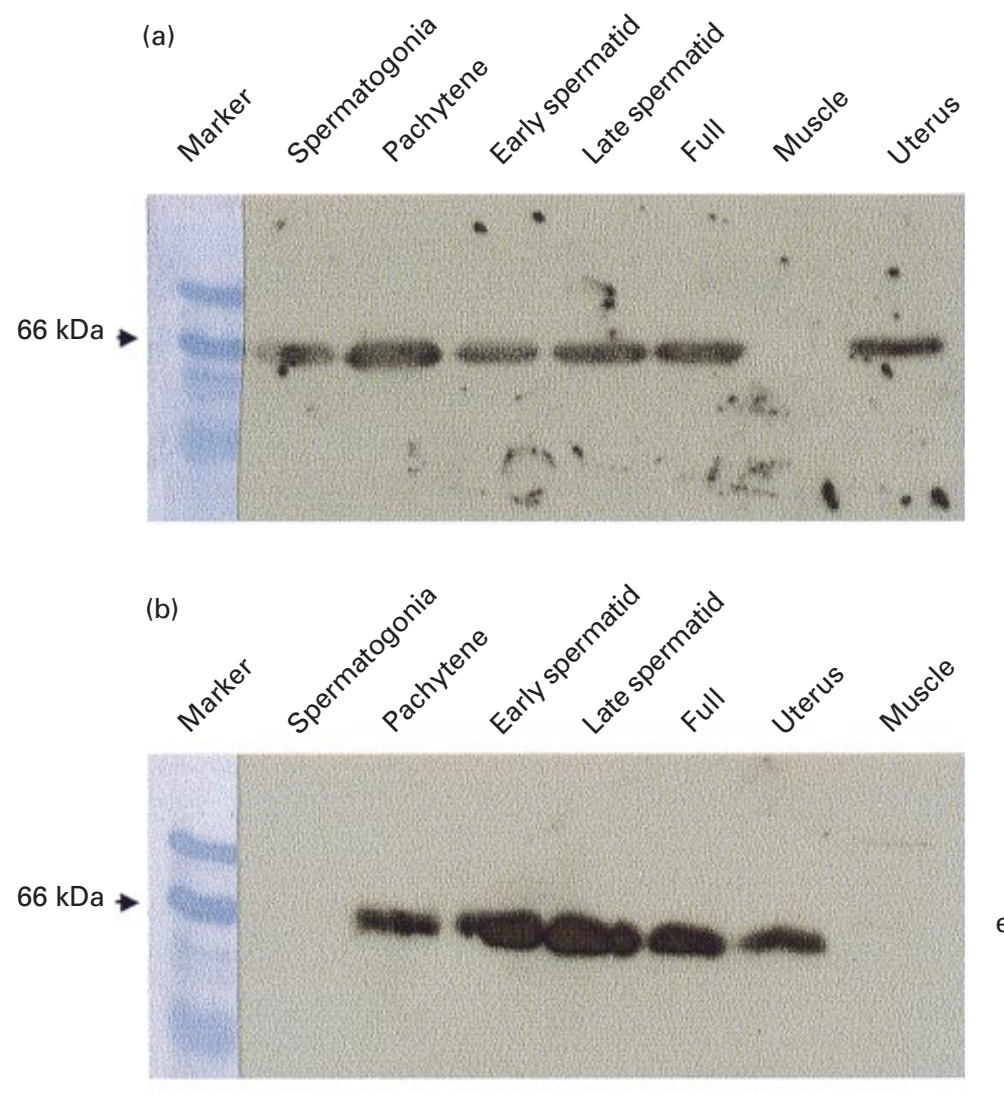

Caput epididymis

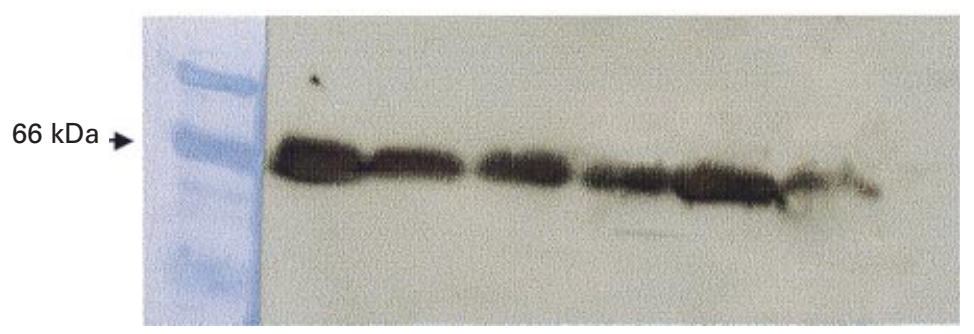

Cauda

epididymis

Fig. 3. (a) Western blot analysis of membrane preparations from ram testis at defined stages during the first spermatogenic cycle. Total protein $(200 \mu \mathrm{g})$ was loaded per lane. Gels were probed with antiserum 020. Uterus and muscle tissue were included as positive and negative controls, respectively. (b) Western blot analysis of membrane preparations from ram epididymides at defined stages during the first spermatogenic wave. Total protein $(200 \mu \mathrm{g})$ was loaded per lane, except for the caput epididymal tissue during the spermatogonia stage, in which case no tissue was available. Gels were probed with antiserum 020. Uterus and muscle tissue were included as positive and negative controls, respectively.

$5 \mathrm{~A})$, whereas in the cauda epididymis, there was weak staining of the peritubular smooth muscle layer (Fig. 5B). These patterns of oxytocin receptor localization were independent of the stage of development of the spermatogenic cycle.

In the ductus deferens, staining for oxytocin receptors was present in all of the epithelial cells surrounding the lumen. No staining for oxytocin receptors was present in the layer of longitudinal smooth muscle that immediately surrounds the epithelium of the ductus, but staining was present in the circular smooth muscle layer (Fig. 6).

\section{Discussion}

If oxytocin is to be regarded as playing a role in male reproductive function, it is not only necessary that the peptide and its cognate receptor are present in the reproductive tissues, but also that an identifiable physiological action can be ascribed to them. The present study demonstrates that oxytocin may promote shedding of spermatozoa or the transport of spermatozoa through the testis. As oxytocin did not affect testicular mass after efferent duct ligation, it would appear that oxytocin does not alter the 

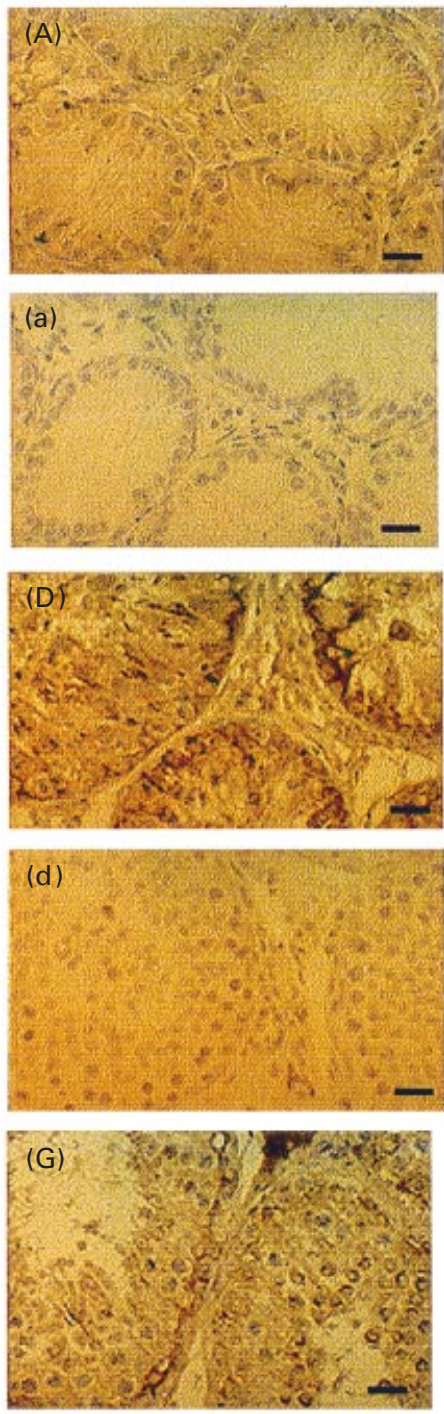
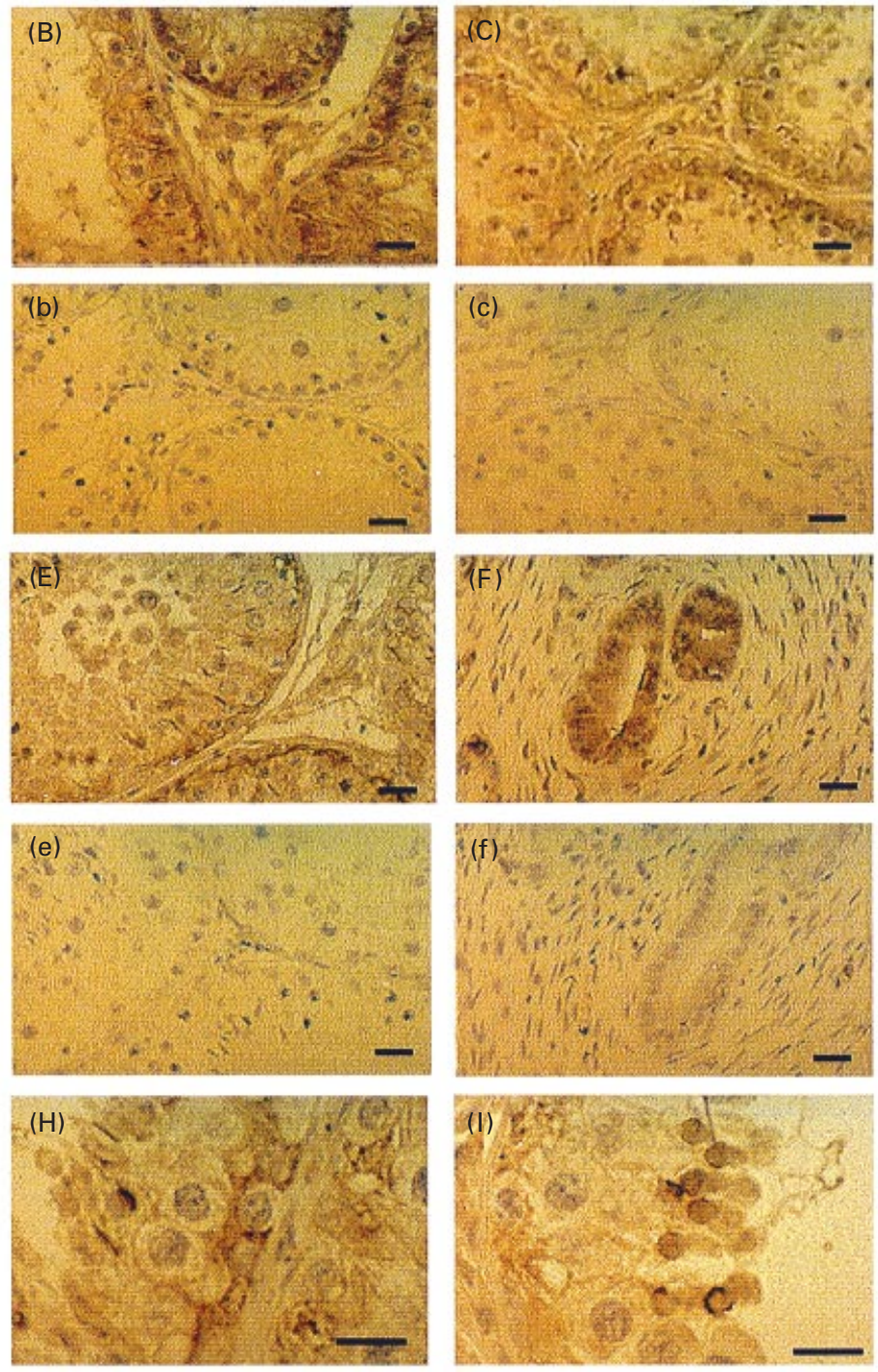

Fig. 4. Immunocytochemistry showing oxytocin receptor localization in the ram testis at different stages during the first spermatogenic wave: (a) only spermatogonia present, (b) presence of pachytene spermatocytes, (c) presence of early spermatids, (d) presence of late spermatids and (e) full spermatogenesis. Tissues labelled with uppercase letters (A-E) were incubated with antiserum 020, whereas those labelled with lowercase letters (a-e) were incubated with whole rabbit serum in place of antiserum 020. Sections of rat uterus $(\mathrm{F}, \mathrm{f})$ were included as a positive control. $(\mathrm{G}, \mathrm{H})$ Testis section at full spermatogenesis showing the concentrated localization of staining with antiserum 020 in the basal compartment of the seminiferous tubule. (I) Testis section at full spermatogenesis showing the localization of antiserum 020 staining to some stages of round or elongating spermatids. Scale bars represent $100 \mu \mathrm{m}$.

rate of fluid secretion by the seminiferous tubules. However, oxytocin increased the concentration of spermatozoa in the rete testis fluid, an effect that may have been a result of either a change in the rate of transport of spermatozoa within the testis or an increase in the number of spermatozoa shed by the seminiferous epithelium. Treatment with an oxytocin antagonist inhibited this response demonstrating that the effect was specifically dependent on oxytocin.

Evidence to support the notion of specific effects of oxytocin on intratesticular sperm transport is derived largely from studies in rats. For example, treatment of pubertal rats with exogenous oxytocin in vivo promotes spermiation, whereas administration of an oxytocin antagonist delays this process (Frayne et al., 1996). Moreover, in rats, oxytocin increases the contractility of the wall of the seminiferous tubule in vitro in a stage-specific manner (Harris and Nicholson, 1998). The mechanism by which oxytocin causes these contractions is not clear. Although oxytocin receptors have been observed in the myoid cells of the rat 

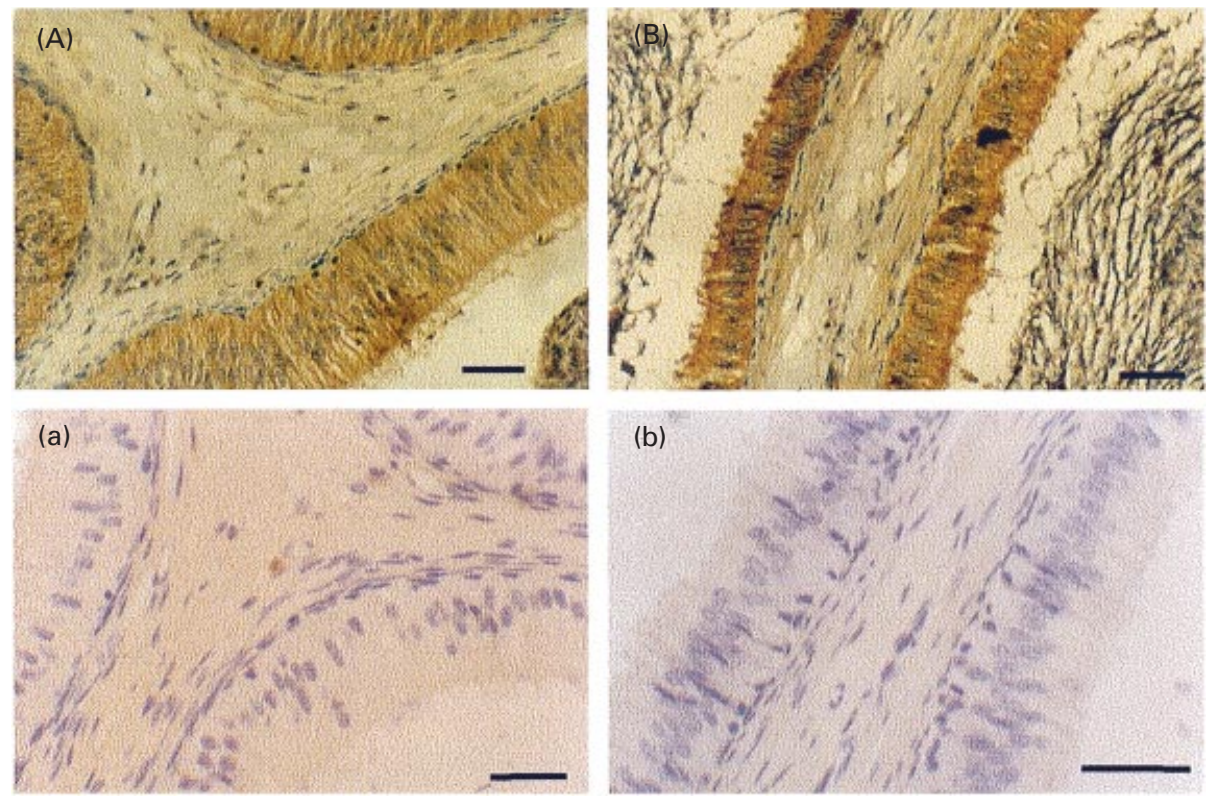

Fig. 5. Immunocytochemistry showing oxytocin receptor localization in the epididymis of a mature ram: (a) caput epididymidis and (b) cauda epididymidis. The tissues labelled with uppercase letters $(A, B)$ were incubated with antiserum 020 and those labelled with lowercase letters $(a, b)$ were incubated with whole rabbit serum in place of antiserum 020. Scale bars represent $100 \mu \mathrm{m}$.

testis (C. Johnson, unpublished), other studies have failed to demonstrate the presence of such receptors on the myoid cells of human, macaque or marmoset monkey testes (Einspanier and Ivell, 1997; Frayne and Nicholson, 1998). Similarly, the present study was unable to show conclusively the presence of oxytocin receptors on myoid cells of the ram testis. It is not yet clear whether this finding reflects a lack of receptors on the testicular myoid cells of rams or whether further refinement of the staining technique is required for ovine tissue.

Species differences in cellular localization of oxytocin receptors may initially seem counter-intuitive, but it is an effect that is not without precedent. In the rat testis, Leydig cells are the predominant type of cell that expresses the oxytocin receptor (Bathgate and Sernia, 1994), whereas Sertoli cells express only a few receptors (C. Johnson, unpublished). This finding is in contrast to results from the present study in ram testis, in which Sertoli cells appear to be the major type of cell expressing oxytocin receptors. Such differences in localization of oxytocin receptors within the Leydig and Sertoli cells of these two species may compensate for the differences in the patterns of myoid cell staining that they express. Moreover, it is possible that oxytocin causes seminiferous tubule contractions indirectly, that is, via stimulation of the release of factors that subsequently cause myoid cell contraction. Endothelin is a possible candidate for such a factor, as it is synthesized within the Sertoli cells of the seminiferous tubule (Tripiciano et al., 1999) and stimulates myoid cell contraction through stimulation of specific myoid cell receptors (Tripiciano et al., 1996).

An additional function of oxytocin that is indicated by the presence of its receptors in Sertoli cells is the regulation of steroid production. In the adult testis, Sertoli cells are the main site of the enzyme $5 \alpha$-reductase, the enzyme responsible for the irreversible conversion of testosterone to its more active metabolite, dihydrotestosterone. In the reproductive system of rats, the activity of this enzyme is regulated by oxytocin (Nicholson and Jenkin, 1994, 1995). Therefore, the observation in the present study of oxytocin receptors on Sertoli cells may indicate that oxytocin is also involved in the regulation of testicular steroidogenesis in rams, by influencing $5 \alpha$-reductase activity.

The epididymis is dependent on androgens, especially dihydrotestosterone, for growth and maintenance of its functions. The epithelial cells of the epididymis contain $5 \alpha-$ reductase, which contributes to the maintenance of local concentrations of dihydrotestosterone. As these epithelial cells also express oxytocin receptors, oxytocin may regulate the production of dihydrotestosterone in the epididymis in an analogous way to that proposed for the testis. Oxytocin has been shown to increase sperm transit within the epididymis (Voglmayr, 1975; Nicholson et al., 1999), a role that is supported by cellular localization of oxytocin receptors. The route by which oxytocin activates its receptors is unclear. It is possible that oxytocin is transported within the epididymal fluid (Knickerbocker et al., 1988), although, if this were the case, it would be 

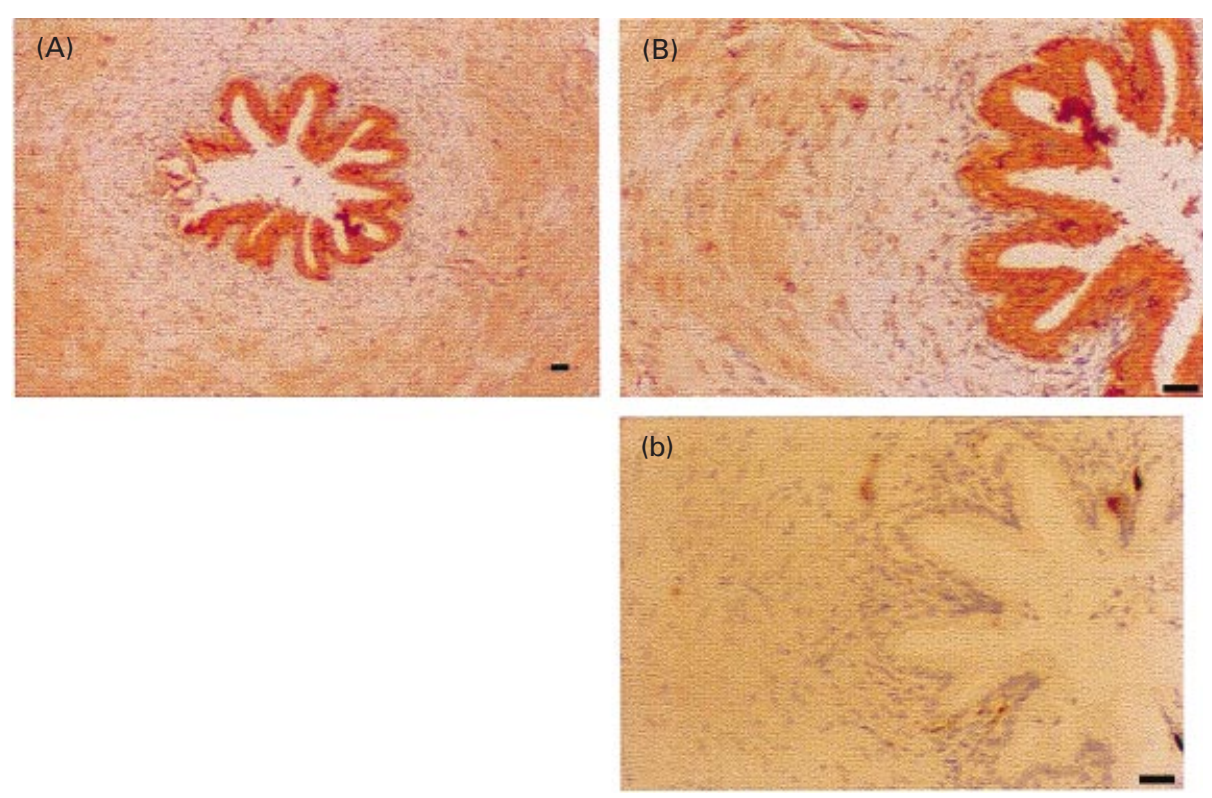

Fig. 6. Immunocytochemistry showing oxytocin receptor localization in the ductus deferens of rams. The tissues labelled with uppercase letters $(A, B)$ were incubated with antiserum 020, whereas the tissue labelled with the lowercase letter was incubated with whole rabbit serum in place of antiserum 020 to determine non-specific staining (b). Scale bars represent $100 \mu \mathrm{m}$.

expected that oxytocin receptors would be present on the luminal surface of the epithelial cells. As the results of the present study showed that this was not the main site of the receptors, such a route of delivery seems unlikely. However, other studies in our laboratory have shown that oxytocin is synthesized within the epithelial cells, indicating a paracrine/autocrine role for this peptide within the epididymis (Assinder et al., 2000). The localization of oxytocin receptors changes along the length of the epididymis. In the caput region, receptors are localized to epithelial cells only. In contrast, in the cauda epididymidis, oxytocin receptors are present in the smooth muscle layers surrounding the ducts in addition to the epithelial cells. The significance of this pattern of distribution of receptors is unclear. However, the presence of receptors in the muscle cells of the cauda epididymis is compatible with the contractility of that part of the organ that occurs during coitus and ejaculation.

Transport of spermatozoa through the ductus deferens is increased by oxytocin (Ewy et al., 1963; Bielanski and Ewy, 1966). A role for oxytocin in promoting sperm transit through the ductus deferens is supported by localization of oxytocin receptors on the circular muscle surrounding the vas deferens.

In summary, oxytocin has been implicated in the local regulation of steroidogenesis and in the modulation of sperm transport in the male reproductive tract. The present study provides evidence that the peptide may play a role in the movement of spermatozoa within the ram testis and also demonstrates the presence of oxytocin receptors in the testis, epididymis and ductus deferens of rams. The cellular localization of receptors supports a role for oxytocin in the regulation of steroidogenesis and in reproductive tract contractility.

\section{References}

Adan RAH, Van Leeuwen FW, Sonnemans MAF, Brouns M, Hoffman G, Verbalis JG and Burbach JPH (1995) Rat oxytocin receptor in brain, pituitary, mammary gland and uterus: partial sequence and immunocytochemical localisation Endocrinology 136 4022-4028

Assinder SJ, Carey M, Parkinson TJ and Nicholson HD (2000) Oxytocin and vasopressin expression in the ovine testis and epididymis: changes with the onset of spermatogenesis Biology of Reproduction 63 448-456

Bathgate RAD and Sernia C (1994) Characterisation and localisation of oxytocin receptors in the rat testis Journal of Endocrinology 141 343-352

Bielanski W and Ewy Z (1966) Sperm transport through the vas deferens of the ram Zeszyty Problemowe Postepow Nauk Rolniczych 61 35-40 (As cited in Animal Breeding Abstracts (1968) 36251 Abstract 1560)

Bodanszky M, Sharaf H, Roy JB and Saids I (1992) Contractile activity of vasotocin, oxytocin and vasopressin on mammalian prostate European Journal of Pharmacology 216 311-313

Einspanier A and Ivell R (1997) Oxytocin and oxytocin receptor expression in reproductive tissue of the male marmoset monkey Biology of Reproduction $\mathbf{5 6}$ 416-422

Ewy Z, Bielanski W and Zapletal Z (1963) Influence of oxytocin on spermatozoa transport in the ductus deferens of the ram Bulletin de l'Academie Polonaise Sciences - Series des Sciences Biologique 11 145-148 (As cited in Animal Breeding Abstracts (1963) 31492 Abstract 2955)

Frayne J and Nicholson HD (1995) Effect of oxytocin on testosterone production by isolated rat leydig cells is mediated via a specific oxytocin receptor Biology of Reproduction 52 1268-1273

Frayne J and Nicholson HD (1998) Localisation of oxytocin receptors in the human and macaque monkey male reproductive tract: evidence for a physiological role of oxytocin in the male Molecular Human Reproduction 4 527-532 
Frayne J, Townsend D and Nicholson HD (1996) Effects of oxytocin on sperm transport in the pubertal rat Journal of Reproduction and Fertility $107299-306$

Harris GC and Nicholson HD (1998) Characterisation of the biological effects of neurohypophysial peptides on seminiferous tubules Journal of Endocrinology 156 35-42

Hib J (1974) The in vitro effects of oxytocin and vasopressin on spontaneous contractility of the mouse epididymis Biology of Reproduction $\mathbf{1 1}$ 436-439

Howl J, Rudge SA, Lavis RA, Davies ARL, Parslow RA, Hughes PJ, Kirk CJ, Michell RH and Wheatley M (1995) Rat testicular myoid cells express vasopressin receptors: receptor structure, signal transduction and developmental regulation Endocrinology 136 2206-2213

Knickerbocker JJ, Sawyer HR, Amann RP, Tekpetey FR and Niswender GD (1988) Evidence for the presence of oxytocin in the ovine epididymis Biology of Reproduction 39 391-397

Knight TW (1974) A qualitative study of factors affecting the contractions of the epididymis and ductus deferens of the ram Journal of Reproduction and Fertility 40 19-29

Maggi M, Malozowski S, Kassis S, Guardabasso V and Rodbard D (1987) Identification and characterisation of two classes of receptors for oxytocin and vasopressin in porcine tunica albuginea, epididymis and vas deferens Endocrinology 120 986-994

Manning M, Miteva K, Pancheva S, Stoev S, Wo NC and Chan WY (1995) Design and synthesis of highly selective in vitro and in vivo uterine receptor antagonists of oxytocin: comparisons with Atosiban International Journal of Peptide and Protein Research $\mathbf{4 6}$ 244-252

Nicholson HD and Jenkin L (1994) Oxytocin increases $5 \alpha$-reductase activity in the rat testis. In Function of Somatic Cells in the Testis pp 278-285 Ed. A Bartke. Springer-Verlag, New York

Nicholson HD and Jenkin J (1995) Oxytocin and prostatic function. In Oxytocin pp 529-538 Eds R Ivell and J Russell. Plenum Press, New York
Nicholson HD, Guldenaar SEF, Boer GJ and Pickering BT (1991) Testicular oxytocin: effects of intratesticular oxytocin in the rat Journal of Endocrinology 130 231-238

Nicholson HD, Parkinson TJ and Lapwood KR (1999) Effects of oxytocin and vasopressin on sperm transport from the cauda epididymis in sheep Journal of Reproduction and Fertility 117 299-305

Setchell BP (1970) The secretion of fluid by the testis of rats, rams and goats with some observations on the effects of age, cryptorchidism and hypophysectomy Journal of Reproduction and Fertility 23 79-85

Tripiciano A, Filippini A, Giustiniani Q and Palombi F (1996) Direct visualization of rat peritubular myoid cell contraction in response to endothelin Biology of Reproduction 55 25-31

Tripiciano A, Peluso C, Morena AR, Palombi F, Stefanini M, Ziparo E, Yanagisawa M and Filippini A (1999) Cyclic expression of endothelinconverting enzyme-1 mediates the functional regulation of seminiferous tubule contraction Journal of Cell Biology 145 1027-1038

VogImayr JK (1975) Output of spermatozoa and fluid by the testis of the ram and its response to oxytocin Journal of Reproduction and Fertility $\mathbf{4 3}$ $119-122$

Worley RTS, Appleton MAC, Lyburn ID, Challis JR and Pickering BT (1988) Concentration dependent stimulation of seminiferous tubule contractility by oxytocin and its modification by peptide analogues Proceedings of the 10th North American Testis Workshop; Regulation of Testicular Function, Serono, USA, Poster 29

Xuan W, Verbalis JG, Hoffman GE, Derks JB and Nathanielsz PW (1996) Characterisation of oxytocin receptor expression and distribution in the pregnant sheep uterus Endocrinology 137 722-728

Received 12 February 2001.

First decision 3 April 2001

Accepted 18 April 2001. 